\title{
Challenges and extents of Soil and Water Conservation measures in Guba-Lafto Woreda of North Wollo, Ethiopia
}

\author{
Belay Asnake $^{1^{*}}$ and Eyasu Elias ${ }^{2}$ \\ ${ }^{1}$ Department of Natural Resource Management, Samara University, College of Dry Land Agriculture, Semera, P.O.Box \\ 132, Ethiopia \\ ${ }^{2}$ Associate Professor at Centre for Environmental Science, Addis Ababa University, Addis Ababa, P.O.Box 1176, \\ Ethiopia
}

Accepted 24 February, 2017

This study was conducted to assess the main challenges and extents of implementation of soil and water conservation measures (SWC) measures in Guba-Lafto Woreda of North Wollo, Ethiopia. Two case study kebeles were purposively selected representing Dega (highland) and Woina dega (midland) agro ecological zones. A total of 130 households were selected for farmer level assessment of the main challenges and level of implementation of SWC measures. The study found that the major SWC measures being employed in were physical SWC measures (stone bund, hillside terrace, micro water ponds, stone faced soil bund, check dam, and fanya-juu terrace); agronomic conservation measures (contour farming, agroforestry, mixed cropping, and crop rotation) ; and biological conservation measures (afforestation, area closure, and grass strip). This study also indicates that, even if the adopted SWC measures were essential to enhance soil fertility, lack of awareness on SWC, land shortage, labour shortage, and wealth status of the farmers were challenging the households to implement SWC practices on their farmlands. Following these, farmers need to be encouraged to implement SWC measures through the use of the productive safety net and Food-for Work payments. Ethiopian federal and local governments should also support and encourage different interventions like increasing fallowing period, reducing intensive cultivation in hilly land, integrated use of SWC practices, and extension of micro-irrigation systems to replenish the degraded soil characteristics and to improve crop production.

Key words: challenges, extents, Soil and water conservation measures,

\section{INTRODUCTION}

\section{Background}

Crop production systems are expected to produce food to keep pace with the global population that will amount to 9.1 billion people in 2050 and over 10 billion by the end of the century (UNFPA, 2011). The population of the world is growing by approximately one billion people per decade. Land degradation and consequent decline in soil fertility has become a serious threat to agricultural

*Corresponding authors E mail: belayasnake2005@gmail.com productivity in Sub-Saharan Africa (Smaling and Storvogel, 1990). The declining fertility of soils because of soil nutrient mining is regarded as a major cause of decreased crop yields and per capital food production in Africa; and decreasing soil fertility accompanied with increasing population pressure is one of the major causes of the gap between demand for and supply of food (Henao and Baanante, 2006).

Agriculture in Ethiopia is not only an economic activity but also a way of life for which agricultural land is an indispensable resource upon which the welfare of the 
society is dependent on. Such dependence obviously leads to increased vulnerability of the economy to problems related to land degradation (Wagayehu, 2003). Although land provides a means of livelihood, land degradation in the form of soil erosion, soil fertility depletion, deforestation through clearance for cultivation and overgrazing is among the basic problems facing farmers in the Ethiopian highlands. The Ethiopian highlands have been experiencing declining soil fertility and severe soil erosion due to intensive farming on steep and fragile land (Aklilu Amsalu, 2006).

Even if the government of Ethiopia has made several interventions, the country still loses tremendous amount of fertile topsoil, and the threat of land degradation is broadening alarmingly (Teklu and Gezahegn, 2003).

According to FAO (2011), soil fertility need to be maintained, agricultural systems need to be transformed to increase the productive capacity and stability of small holder crop production. Greater attention is thus being given to alternative means of intensification, particularly the adoption of soil and water conservation (SWC) practices.

According to Braun et al. (2003), implementation of SWC practices improves soil fertility and increases crop productivity, which enables farmers to grow more food, which translates into better diets and under market conditions that offer a level playing field, into higher farm incomes.

SWC measures are increasing food production without further depleting soil and water resources, adding high amounts of biomass to the soil, causing minimal soil disturbance, conserving soil and water, restoring soil fertility, and increasing the resilience of farming systems to climatic risk (FAO, 2009, 2010c). Thus, this study was designed to examine the challenges and level of implementations of Soil and Water Conservation measures in Guba-Lafto Woreda.

\section{Method of the study}

\section{Description of the Study Area}

Figure 2.1 presents the location map of Guba-Lafto Woreda within the Amhara Region of Ethiopia. The Woreda is bordered in the south by the South Wollo Zone, Delanta and Wadla Woreda in the west, Meket Woreda in the north-west, Gidan Woreda in the northeast by the Logiya River which separates it from Kobo, and on the southeast by Habru. Woldiya is an enclave inside this Woreda and it is the major town in the area. Geographically the area is located between $39^{\circ} 6^{\prime} 9^{\prime \prime}$ and $39^{\circ} 45^{\prime} 58^{\prime \prime}$ East and $11^{\circ} 34$ '54"'and $11^{\circ} 58^{\prime} 59^{\prime \prime}$ North.

Based on the 2014/2015 national census conducted by the Central Statistical Agency of Ethiopia (CSA), with an area of 900.49 square kilometers, Guba-Lafto Woreda has a population of 139,825 , an increase of $0.48 \%$ over the 1994 census. The topography of the Woreda is mostly characterized by a chain of mountains, hills and valleys ranging from 1379- 3809 meter above sea level ( $m$ a.s.l). Guba-Lafto Woreda has there agro-ecological zones, namely, lowland (Kolla) 1379-1500 m a.s.l, Mid-altitude (Woinadega) 1500-2300 m a.s.l, and Highland (Dega) 2300-3200 m a.s.l. Most of the rural population is settled on the highlands and plateaus.

A bi-modal nature of rainfall characterizes most parts of Guba-Lafto Woreda. The short rainy season (Belg), occurs between February and April while the long rainy season (Meher), occurs between June and September. Figure 2.2 shows mean historical monthly temperature and rainfall for Guba Lafto Woreda during the time period 1990-2012. Dominant soil types in the area are Eutric Leptosols, while Eutric Cambisols, Lithic Leptosols, and Vertic Cambisols are also observed in the Woreda (Ali Mohammed, 210). It is reported that, the land use pattern of the Woreda includes arable land (34.1\%), grazing land $(17.9 \%)$, forest $(27.1 \%)$, and water bodies $(6 \%)$, rocky land $(5 \%)$ and others $(9.9 \%)$, respective (Dereje Mengistie and Desale Kidane , 2016).

\section{Types and Source of Data}

The study applied combination of primary and secondary data sources. Primary sources were obtained from household survey, group discussion, and personal observation. While books, articles, journals, legal documents, and website sources were compromise secondary sources of data.

\section{Qualitative Data Sources}

\section{Direct Observation}

This study was carried out through systematic watching, listening and recording of data. It helps to generate ideas helpful to modify questionnaire for survey, group discussion and key informant interview and also to acquire information about the physical setting of the area, conditions of land degradation, and status of the present soil and water conservation practices.

\section{Focus Group Discussion}

Total of two focus group discussions were administered from two kebeles. The group members were included total member of 6 who are 2 elders, 2 religious leaders, and 2 teachers from both men and women. The aim of the discussion was on extent and major challenges to adopt SWC practices which used to enhance soil fertility and supporting crop productivity. 


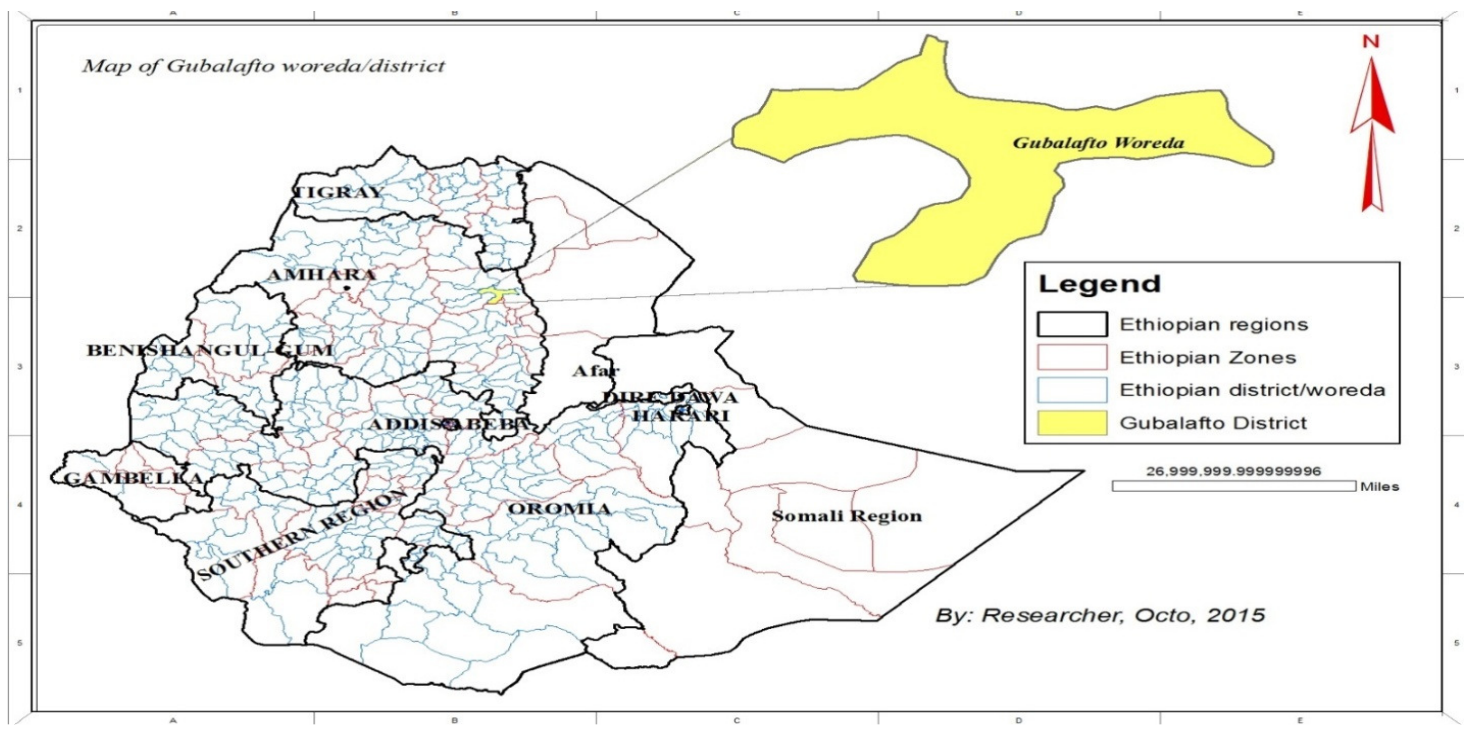

Figure 2.1: Location map of the study area

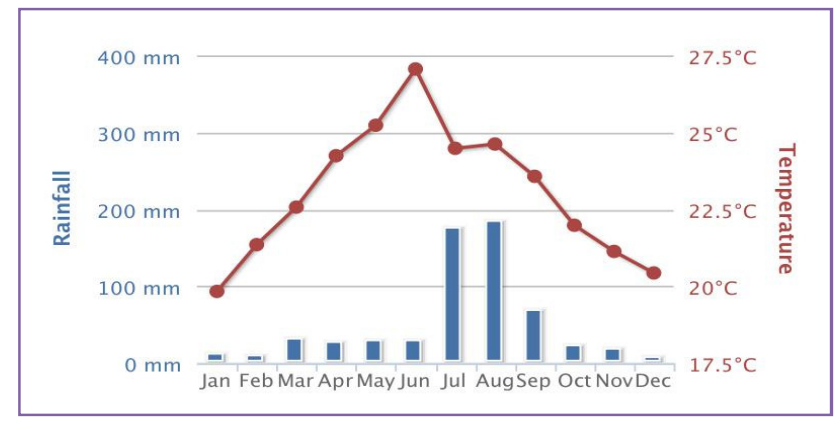

Figure 2.2: Average monthly temperature and rainfall at Woreda from 1990-2012

Source: World Bank, 2016

\section{Key Informant Interview}

For the sake of in depth understanding of challenges and extents of soil and water conservation measures in the study area, the researchers had conducted in-depth interview with kebele administrator and one development abent (DA) totally 2 key informants in each kebeles. All these key informants had better understanding on challenges and extents of soil and water conservation measures in the study area.

\section{Quantitative Data Sources}

\section{Household Survey and Data Analysis}

Questionnaire survey was applied to collect primary data from sampled households using structured questionnaire. Key topics covered in the questionnaire include demographic and socio-economic characteristics of households; major challenges and implementation status of soil and water conservation measures.

Kebeles in the Woreda were stratified in to two agroecological zones highland and midland. One kebeles from each agro ecological zone totally two kebeles; Shewat kebele (highland), and Amaymicha kebele (midland) have been selected purposively as SWC practices are more available in these kebeles. These kebele provide us an opportunity to find out different SWC measures and to investigate the challenges and extents of these measures in the study area. From selected kebeles, a total 130 representative households were selected proportionally (90 from Shewat, and 41 from Amaymicha).

The sample size household is determined by using the following formula with some degree of precision for general household head (Cochran, 1977). 
Table3.1: Physical SWC measures employed across kebeles

\begin{tabular}{|c|c|c|c|c|c|c|}
\hline \multirow[t]{2}{*}{ Physical SWC measures } & \multicolumn{2}{|c|}{ Shewat } & \multicolumn{2}{|c|}{ Amaymicha } & \multicolumn{2}{|c|}{ Total } \\
\hline & $\mathbf{N}$ & $\%$ & $\mathbf{N}$ & $\%$ & $\mathbf{N}$ & Percent \\
\hline Stone faced soil bund & 83 & $63.8 \%$ & 37 & $28.7 \%$ & 119 & $92.2 \%$ \\
\hline Hillside terrace & 82 & $63.1 \%$ & 37 & $28.5 \%$ & 119 & $91.5 \%$ \\
\hline Stone bund & 60 & $46.2 \%$ & 23 & $17.7 \%$ & 83 & $63.8 \%$ \\
\hline Check dam & 27 & $20.8 \%$ & 11 & $8.5 \%$ & 38 & $29.2 \%$ \\
\hline Micro water ponds & 74 & $56.9 \%$ & 29 & $22.3 \%$ & 103 & $79.2 \%$ \\
\hline Fanya-juu & 11 & $8.5 \%$ & 5 & $3.8 \%$ & 16 & $12.3 \%$ \\
\hline
\end{tabular}

$$
n=\frac{N Z^{2} P Q}{d^{2}(N-1)+Z^{2} P Q}
$$

Where: $\mathrm{n}=$ sample size of housing units (household head); $P=$ Housing unit variable (residential houses); $Q=$ Non-residential houses (different sectoral offices, schools, etc. in terms of percentage) $=1-\mathrm{P} ; \mathrm{N}=$ Total number of housing units (1921); $Z=$ Standardized normal variable and its value that corresponds to $95 \%$ confidence interval equals 1.96; $d=$ Allowable error $(0.05)$ and after calculated $n$ is Sample size $(n)=130$.

\section{RESULT AND DISCUSSION}

\section{Socio-economic Conditions of Households}

\section{The age characteristics of the sample}

household respondents from18-25 years old were accounted for $23.1 \%$ in Shewat, and $9.2 \%$ in Amaymicha kebeles. The household members whose age is above 60 were accounted for $5.4 \%$ in Shewat, and $3.1 \%$ in Amaymicha kebeles. The number of family in a household is somewhat reducing due to the implementation of family planning strategies and immigration of rural youngsters to the urban areas". Out of the total respondents of two kebeles, 81 are maleheaded and the remaining $19 \%$ are female-headed. $35.4 \%$ of the respondents are illiterate; $20.0 \%$ have completed primary school; $14.6 \%$ of the respondents were completed secondary school; and $30.0 \%$ of the respondents were diploma and first degree holders. Key employment reported by respondents can be divided in to crop farming, mixed farming (53.1\%), pastoralist, wage labour, and civil servant.

\section{SWC practices Being Employed by Farmer}

\section{Physical Conservation Measures}

\section{Stone Faced Soil bund}

Table 3.1 presents that, level of stone faced soil bund in the study area (92.2\%). Stone Faced Soil bund act on slopes from $0-30 \%$ (depending on rainfall, soil type and land use) both by interrupting slope length and by reducing its gradient. With proper maintenance, this may eventually lead to terrace formation by moving and compacting soil downhill (FAO, 1986).

\section{Hillside terraces}

Table 3.1 shows that, the extent of adoption of hillside terraces were $91.5 \%$. When we see the extent of hillside terraces across the kebeles, Shewat kebele $(63.1 \%)$ was dominated Amaymicha (28.5\%). This also shows that there were more hilly and mountains farmlands in Shewat kebele. Hillside terraces used to reduce surface erosion by rainfall runoff; retain runoff for moisture conservation; promote establishment trees and shrubs; and safely control the flow of water by diverting runoff from upland sloping areas or collection zones to a stable outlet sloping upland or collection zone (Nyssen , 2007).

\section{Stone bund}

Stone bund was also practicable soil and water conservation measures in the Woreda (63.8\%). When we see the level of adoption of stone bund across the kebeles, Amaymich kebele (17.7\%) was dominated by Shewat $(46.2 \%$ (Table 4.7$)$.

According to key informant respondents, if large stones are plentiful on the land, these may be used to make the bunds. Under water limiting conditions, the stone bunds are efficient measures to improving soil water content through runoff control (MoARD, 2005). When rainfall is erratic, the stone bunds contribute to conserving more moisture in the soil for longer, which helps to alleviate water stress during dry spells (Figure 3.1).

\section{Check dam}

Comparing to stone bund and hill side terrace, check dam was also slightly being implemented in the Woreda $(29.2 \%)$. When we see the level of adoption of check dam across the kebeles, Shewat kebele (20.8\%) was 


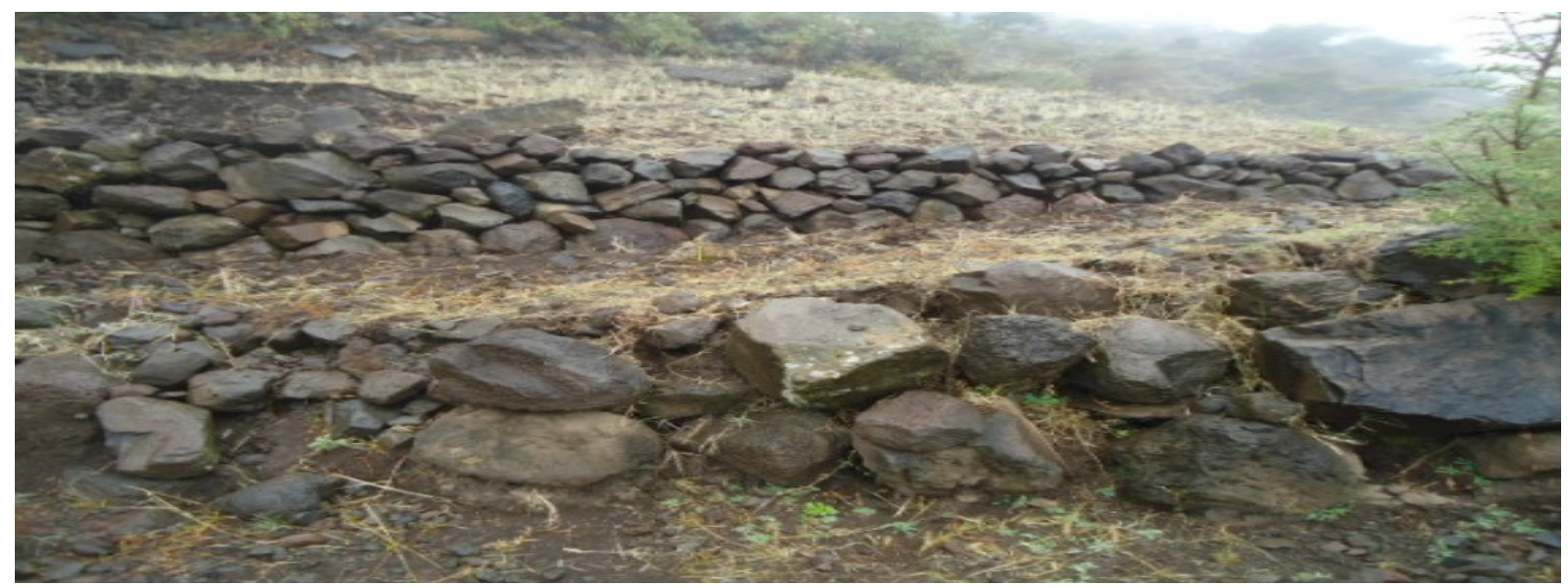

Figure 3.1: Stone bund in Guba-Lafto Woreda

Table3.1: Physical SWC measures employed across kebeles

\begin{tabular}{lllllll}
\hline Physical SWC measures & \multicolumn{3}{l}{ Shewat } & \multicolumn{2}{l}{ Amaymicha } & Total \\
\hline & $\mathbf{N}$ & $\%$ & $\mathbf{N}$ & $\%$ & $\mathbf{N}$ & Percent \\
\hline Stone faced soil bund & 83 & $63.8 \%$ & 37 & $28.7 \%$ & 119 & $92.2 \%$ \\
Hillside terrace & 82 & $63.1 \%$ & 37 & $28.5 \%$ & 119 & $91.5 \%$ \\
Stone bund & 60 & $46.2 \%$ & 23 & $17.7 \%$ & 83 & $63.8 \%$ \\
Check dam & 27 & $20.8 \%$ & 11 & $8.5 \%$ & 38 & $29.2 \%$ \\
Micro water ponds & 74 & $56.9 \%$ & 29 & $22.3 \%$ & 103 & $79.2 \%$ \\
Fanya-juu & 11 & $8.5 \%$ & 5 & $3.8 \%$ & 16 & $12.3 \%$ \\
\hline
\end{tabular}

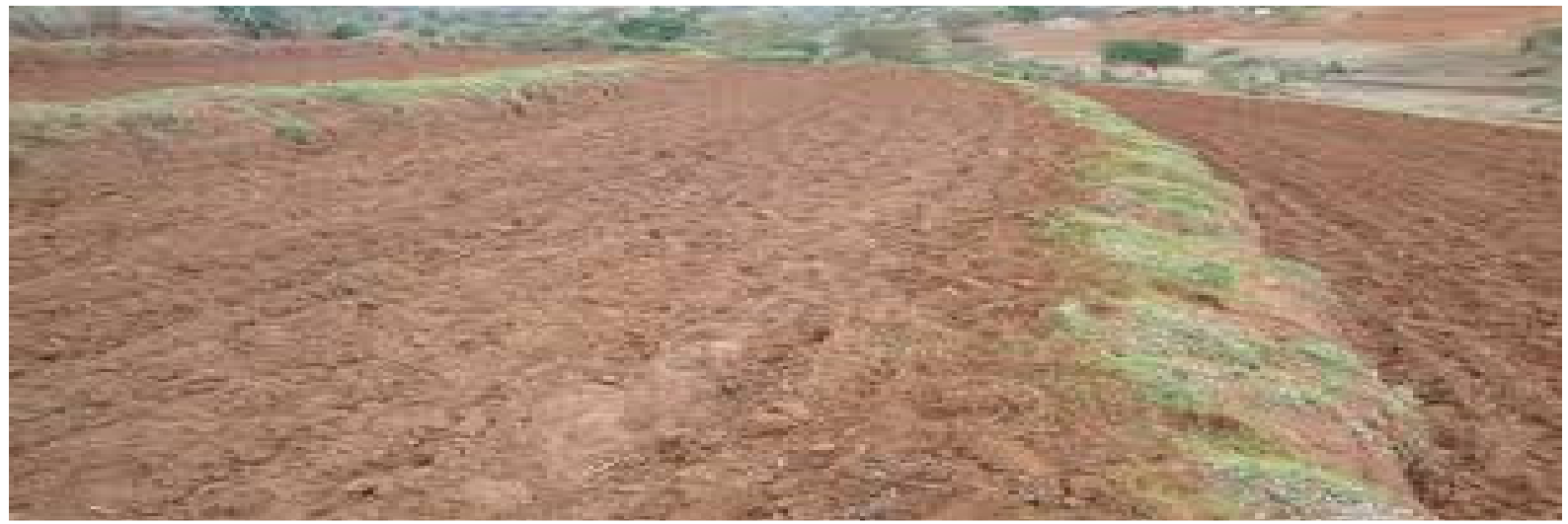

Figure 3.3: Fanya-juu terrace

dominated Amaymicha (8.5\%) kebele. A check dam placed in the ditch, swale, or channel interrupts the flow of water and flattens the gradient of the channel, thereby reducing the velocity of run-off (MoARD, 2005).

\section{Fanya-juu Terrace}

Comparing to other physical SWC measures above,
Fanya-juu terrace was not much implemented in the Woreda (12.3\%). When we see the level of Fanya-juu terrace across the kebeles, Shewat kebele (8.5\%) was dominated Amaymicha kebele (3.8\%) (Table 3.1).

Fanya-juu terraces are constructed by throwing soil up slope from a ditch to form a bund along a contour. Several of these terraces are made up the slope following the contour lines (Figure 3.3). 
Table 3.2: Major agronomic conservation measures in Guba-Lafto Woreda

\begin{tabular}{lllllll}
\hline Agronomic measures & Shewat & \multicolumn{3}{c}{ Amaymicha } & \multicolumn{2}{c}{ Total } \\
\hline & $\mathbf{N}$ & $\%$ & $\mathbf{N}$ & $\%$ & $\mathbf{N}$ & Percent \\
\hline Crop Rotation & 83 & $63.8 \%$ & 33 & $25.4 \%$ & 116 & $89.2 \%$ \\
Mixed cropping & 65 & $50.0 \%$ & 21 & $16.2 \%$ & 86 & $66.2 \%$ \\
Contour plowing & 28 & $20 \%$ & 20 & $15.3 \%$ & 48 & $35.0 \%$ \\
Agroforestry & 12 & $6.7 \%$ & 5 & $2.8 \%$ & 17 & $9 \%$ \\
\hline
\end{tabular}

Table 3.3: Major biological conservation measures in Guba-Lafto Woreda

\begin{tabular}{|c|c|c|c|c|c|c|}
\hline \multirow[t]{2}{*}{ Biological measures } & \multicolumn{2}{|c|}{ Shewat } & \multicolumn{2}{|c|}{ Amaymicha } & \multicolumn{2}{|c|}{ Total } \\
\hline & $\mathbf{N}$ & $\%$ & $\mathbf{N}$ & $\%$ & $\mathbf{N}$ & Percent \\
\hline Afforestation & 80 & $61.5 \%$ & 34 & $26.2 \%$ & 114 & $87.7 \%$ \\
\hline Area closure & 66 & $36.7 \%$ & 28 & $15.6 \%$ & 94 & $52 \%$ \\
\hline Grass strip & 26 & $14.4 \%$ & 19 & $10.6 \%$ & 45 & $25 \%$ \\
\hline
\end{tabular}

\section{Agronomic Conservation Measures}

\section{Crop Rotation}

Crop rotation entails growing various crops on the same piece of land (WDEQ, 2013), is well known agronomic measures in the Woreda (89.2\%). Crop rotation was much implemented in Shewat kebele $(63.8 \%)$ than Amaymicha kebele (25.4\%) (Table 3.2). Crop rotation increases organic matter in the soil, reduce pests and diseases, improves soil structure, reduces soil degradation (Kwesiga et al.,1999).

\section{Mixed Cropping}

Mixed cropping is the practice of growing two or more crops in the same piece of land during a single growing season (WDEQ, 2013). Compare to contour farming, mixed cropping is well known agronomic measures in the Woreda $(66.2 \%)$. Mixed cropping was much implemented in Shewat kebele $(50.0 \%)$ than Amaymicha kebele (16.2\% (Table3.2).

\section{Contour Farming}

Contour farming is also to some extent being implemented in Guba-Lafto Woreda (35.0\%) in which, it is dominated in Shewat kebele $(20 \%)$ followed by Amaymicha kebele (15.3\%) (Table 3.2). The purpose of contour farming is to prevent surface runoff downslope and encourages infiltration of water into the soil. Contour plowing can increase crop yields from 10 to 50 percent, partially as a result from greater soil retention (USDA, 1997).

\section{Biological Conservation Measures}

\section{Afforestation}

In Guba-Lafto Woreda public mobilization in afforestation program is dramatically increasing in the last 10 years. Since the Woreda is endowed with mountainous topography, afforestation is currently becoming the best biological conservation measures in Guba-Lafto Woreda $(87.7 \%)$. When we see the level of implementation, Shewat kebeles (61.5\%) leads Amaymicha kebele (26.2\%) (Table 3.3).

Afforestation and re-forestation programs has made and is making a very substantial contribution to conservation in the Highlands by the reclamation and protection of steep and/or severely degraded slopes, thus reducing run-off, improving water flow and storage regimes, and increasing availability of fuel wood, there by decreasing the proportion of dung and crop residues used for fuel (FAO, 1986).

\section{Area closure}

Recently area closure is becoming public in Guba-Lafto Woreda (52\%). The extent of implementation of area closure in Shewat kebele $(36.7 \%)$ is better than Amaymicha kebele (15.6\%) (Table 3.3).

Area closure directly or indirectly contributes to the increase of crop yields, fodder production and improvement of farm income (Nyssen , 2007).

\section{Grass strip}

In Guba-Lafto Woreda grass strip is not well implemented 
Table 3.4: Challenges to implement SWC practices in Guba-Lafto Woreda

\begin{tabular}{lll}
\hline Challenges to implement SWC practices & \multicolumn{2}{l}{ Responses $\mathbf{( N = 1 8 0 )}$} \\
\cline { 2 - 3 } & $\mathbf{N}$ & Percent \\
\hline Limited awareness on SWC & 107 & $82.3 \%$ \\
Land shortage & 106 & $81.6 \%$ \\
Labour shortage & 78 & $60 \%$ \\
Poor resource endowment & 63 & $48 \%$ \\
\hline
\end{tabular}

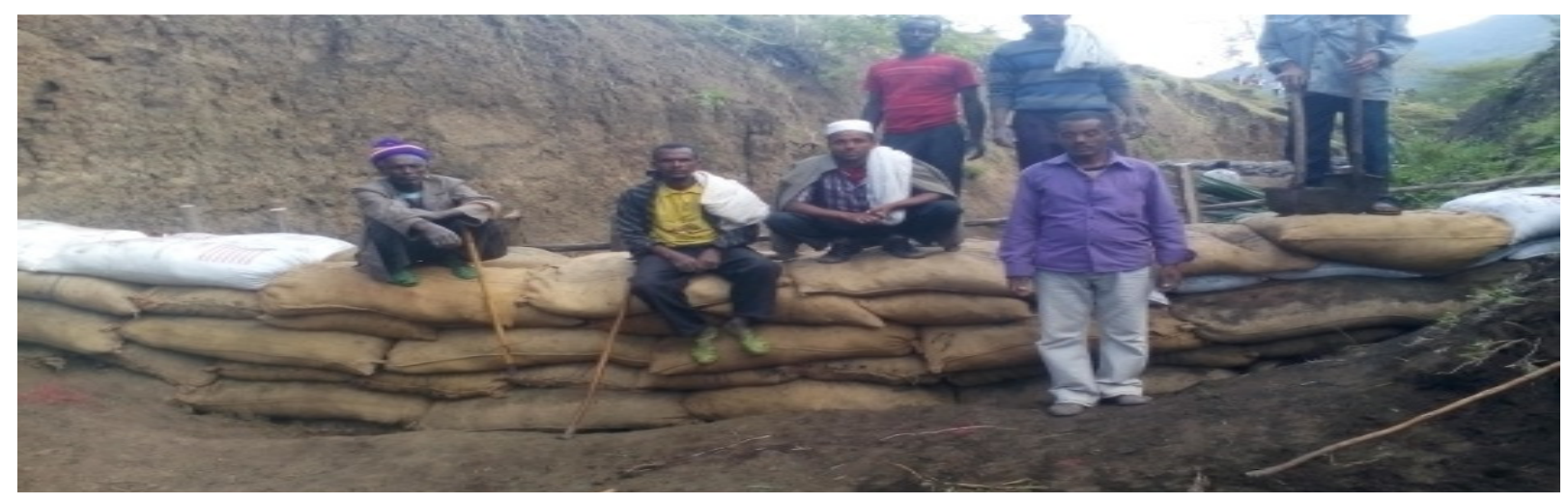

Figure 3.2: Check dams from Sand field bag in Guba-Lafto Woreda

(25\%). But, the degree of implementation of grass strip in Shewat kebele (14.4\%) is better than Amaymicha kebele (10.6\%) (Table 3.3)..

Grass strips uses for the slops of the area from $0-8 \%$ which are alternative to terracing in which Grass is planted in dense strips, up to a meter wide, along the contour. These lines create barriers that minimize soil erosion and runoff, increases soil moisture, and silt builds up in front of the strip (FAO, 1986).

\section{Challenges to Implement SWC Measures}

\section{Limited Awareness on SWC}

Less awareness of the nature and technical requirements of SWC practices as well as lack of awareness on agricultural knowledge and SWC measures are the major challenges which are limiting households to adopt and implement SWC practices at their farmlands (82.3\%) (Table 3.4). Higher education levels are hypothesized to be associated with improved awareness and knowledge regarding conservation measures and the productivity, and effects of erosion may persuade them to choose particular SWC practices (Addisu Damtew, 2011).

\section{Land Shortage}

Land shortage was negatively affecting households in the Woreda related to adoption of SWC measures (81.6\%) (Table 3.4). In Ethiopia, it was recommended that fanya juu occupies $2-15 \%$ of the land area for a slope of 3-15\%, stone bunds occupy $5-25 \%$ for a slope of $5-50 \%$ and soil bunds occupy $2-20 \%$ for a slope of $3-30 \%$ (Teshome et al., 2013). Vancampenhout et al. (2006) estimated that stone bunds occupy about $8 \%$ of the farmland in northern Ethiopia. In experimental plots established in the central highlands of Ethiopia, soil bunds occupy 8.6 percent of cultivable land (Adimassu Tilahun et al., 2012).

\section{Labour Shortage}

Labour shortage specially the number of family size of the households largely influences the adoption of SWC measures in the Woreda $(60 \%)$ (Table 3.4). The construction and maintenance of physical SWC structures require intensive human labour for which machinery has not been developed or introduced in most developing countries. The labour demand appears much more than the requirement for most ordinary farming businesses. The study revealed that, construction of soil bunds requires 75 and 150 persons per day (PD) ha ${ }^{-1}$ in Debre Mewi and Anjeni watersheds, respectively. In those watersheds, stone bunds require $125 \mathrm{PD} \mathrm{ha}^{-1}$ and in the Anjeni watershed fanya juu demands $150 \mathrm{PD} \mathrm{ha}^{-1}$ (Teshome et al., 2013).

\section{Poor Household Resource Endowment}

Wealth statuses of the farmers are influencing the decision of households to 
implement particular SWC measures (48\%) (Table 3.4). The level of net farm income was expected to affect soil and water conservation effort because farmers with higher net income are less likely to be financially constrained to adopt soil and water conservation measures (Addisu Damtew, 2011).

\section{CONCLUSION AND RECOMMENDATIONS}

\section{CONCLUSION}

The study found that, with the help of the NGO projects (e.g. PSNP) and the extension services, farmers are implementing various soil conservation measures primarily the physical structures such as terraces and bunds. The major SWC measures being employed in the Woreda were physical SWC measures (stone bund, stone faced soil bund, check dam, and fanya-juu terrace); agronomic conservation measures (contour farming, mixed cropping, and crop rotation); and biological conservation measures (afforestation, agroforestry, area closure, and grass strip).

Finally this study indicates that, even if the adopted SWC measures were essential to enhance soil fertility, lack of awareness on SWC, land shortage, labour shortage, and wealth status of the farmers were challenging the households to implement SWC practices on their farmlands.

\section{RECOMMENDATIONS}

Above all, to solve soil fertility decline and moisture stress in Guba-Lafto Woreda, the following key recommendations should be taken in to account. The first recommendation is that, farmers need to be encouraged to implement SWC measures through the use of the productive safety net and Food-for Work payments. Secondly, we should increase fallowing period, reducing intensive cultivation in hilly land, integrated use of SWC practices, and extension of micro-irrigation systems could replenish the degraded soil characteristics and improve crop production. Finally, federal and local governments should support and encourage further studies in the Woreda to improve extents of SWC measures and to reduce the major challenges which are influencing implementation of SWC measures.

\section{REFERENCES}

Addisu D (2011). Benefit and challenge of adoption soil conservation techniques in goromt watershed central Ethiopia. Addis Ababa University, Ethiopia.

Adimassu, ZK (2012). Effect of soil bunds on runoff, soil and nutrient losses and crop yield in the Central Highlands of Ethiopia. Land Degrad. Dev. 10.1002/ldr.2182 Resource Management Papers No. 76. Wageningen, the Netherlands.

Aklilu A (2006). Caring for the Land. Best practices in soil and water

Baruah T, Barthakur H (1998). A Textbook of Soil Analysis. Vikas publishing House Pvt. Ltd., New Delhi, India. conservation in Beressa watershed, highlands of Ethiopia. Tropical

Dereje M, Desale K (2016). Assessment of the Impact of Small-Scale Irrigation on Household Livelihood Improvement at Guba Lafto Woreda, North Wollo, Ethiopia.

Estifanos L (2010). Land use land cover Dynamics in Post-Resettlement Areas using Cellular Automata model: The case of Gubalafto Woreda, Thesis submitted for Partial Fulfillment of the Requirements for the Award of the Degree of Master of science In Remote Sensing and GIS. Addis Ababa, Ethiopia.: Addis ababa university.

Eswaran HR (2001). "Land degradation: an overview". "Responses to Land Degradation. Proc. 2nd. International Conference on Land Degradation and Desertification". New Delhi, India: Oxford Press. Retrieved 2012-02-05.

Eyasu E, Daniel F (2000). Managing Fragile Soils: A Case Study from North Wollo. Managing Africa's Soil No. 13.

FAO. (1986). Ethiopian Highlands Reclamation Study, Final Report. Volume 1, Report prepared for the Government of Ethiopia. Rome.

FAO. (2009). Food Security and Agricultural Mitigation in Developing Countries: Options for Capturing Synergies. Rome: Food and Agriculture Organization of the United Nation.

FAO. (2010c). "Climate-Smart" Agriculture. Policies, Practices and Financing for Food Security, Adaptation and Mitigation. Rome: Food and Agriculture Organization of the United Nations.

FAO. (2011). Climate-Smart Agriculture: A Synthesis of Empirical Evidence of Food Security and Mitigation Benefits from Improved Cropland Management. Rome, Italy.

Henao J, Baanante C (2006). Agricultural production and soil nutrient mining in Africa: implications for resource conservation and policy development. International Fertilizer Development Center, Alabama.

Kwesiga FF (1999). SesbaniaSesban Improved Fallows in Eastern Zambia: The inception, development and farmer Enthusiasm.Agroforestry Systems 47: 49-66, 2003.

MoARD. ( 2005). Community based participatory watershed development - a guide line,. Addis Ababa, Ethiopia.

Nyssen J(2007). Understanding the environmental changes in Tigray: a photographic record over 30 years. Tigray Livelihood Papers No.3.

Stoorvogel and Smaling. (1990). Assessment of Soil nutrient Depletion in Sub-Saharan Africa: 1983-2000. Report No. 28,. Wageningen, The Netherlands.

Teshome AD (2013). Financial viability of soil and water conservation technologies in northwestern Ethiopian highlands. Applied Geogr., 37: 139-149.

USDA. (1997). Predicting soil erosion by water, a guide to conservation planning in the Revised Universal Soil Loss Equation, , Agricultural Research Service, Agricultural handbook no.

WDEQ ( Wyoming Department of Environmental Quality). (2013). Cropland Best Management Practice Manual, Conservation Practices to Protect Surface and Ground Water, Document \#13-0036. University of Wyoming. 